\title{
PREPARATION AND EVALUATION OF DRIED SOUP PRODUCED FROM DIFFERENT SWEET POTATO VARIETIES
}

\author{
NASRA A. ABD-ELHAK ${ }^{1}$ and AFAF A. SALEM ${ }^{2}$
}

\author{
${ }^{1}$ Food Technology Research Institute- ARC, Giza, Egypt \\ ${ }^{2}$ Breeding Research Department for vegetable crops, Medicinal and Aromatic, \\ Hort. Research Institute - ARC, Giza, Egypt
}

(Manuscript received 7 March 2017)

\begin{abstract}
$\mathrm{T}$ his study was conducted in El-Kanater El-Khyria Research Station. Kalubia Governorate during two seasons 2014 and 2015 to evaluate three varieties of sweet potatoes, one was recorded at the Institute of Horticulture Research compared to two local varieties (V.B and V.C) cultivated in Egypt and the aim items for use in the work of sweet potato soup rich in nutrients. The results showed that the significant differences were found among three varieties in most traits. Significant differences for plant growth characters (number of branches and leaves on main stem, length of stem main and neck leaf and weight of vin), yield and its component (total yield per plant of tuber roots $/ \mathrm{Kg}$ ), average weight of one storage root $(\mathrm{gm})$, number of tuber roots per plant and average of tuber root (length and diameter). Data showed that ether extract, protein and fiber were significantly higher in local V.B (orange sweet potato) than that found in local V.C (white sweet potato) and new V Min.6 (yellow sweet potato). The data showed that significant differences in total carotenoid and $\beta$ - carotene were found among all the sweet potato cultivated. Mixing whole wheat, skimmed milk and lentil with sweet potato varieties improved the amino acid profile, nutritional quality, protein digestibility and bioavailability of $\beta$ - carotene. The values of calculated protein efficiency ratio (PER) of the soup samples were 2.72 to 3.35 . The findings show that acceptable soup could be produced from the tuber root of different varieties of sweet potato compared to the control soup (without sweet potato). In conclusion, soup sweet potato is recommended for the elderly and small children since it contains more protein and vitamin $A$ which enhances eyesight. The new $V$ Min 6. showed that the highest values in most traits under study could be recommended for using in commercial production and industrial soup.
\end{abstract}

Key words: Amino acids, $\beta$ carotene, nutritional quality, physical properties sensory evaluation, sweet potato, soup.

\section{INTRODUCTION}

Sweet potato (Ipamoea batatas L.) is one of the most important crops in Egypt. It is grown for human consumption and some industrial purposes. Sweet potato skin colors come in various shades of creamy white, yellow-orange, tan, reddish-purple and red. Sweet potato has also been used in the production of purees and these can be used as an ingredient in various products including baby food, 
casseroles, puddings, pies, cakes, bread, restructured fries, patties, soups and beverages, Walter et al., (2001). In Egypt commercial local varieties of sweet potato and six hybrids recorded in Hort. Department were planted and evaluated for yield characteristics by Salem, Afaf (2010). The study of Mwanga et al., (2009) showed that (Happymi), the average yield of the storage root in the cv. Hyppymiis 37.0 ton /ha, which was $52 \%$ higher than that of the control cultivar sinhwangmi. The number of storage root (over $50 \mathrm{gm}$ per plant) was $4.1 \mathrm{gm}$ the average weight storage root was $162.0 \mathrm{gm}$. They added that, the average yield of storage root of cultivar "yeonh wangmi" was 25.1 ton /ha , which was $22 \%$ higher than that of yulmi. The number of storage roots over $50 \mathrm{gm} /$ plant was 3.3 and the average weight of storage root was 128gm. Berhanu and Beniam, (2013) in a study performance evaluation of improved sweet potato (Ipamoea batatas L.) varieties at Gedeo Zone Southern Ethiopia, Results demonstrated that there is significant difference on performance of different sweet potato varieties on vine length, root diameter, yield and tuber root weight. In this study the higher yield and quality was achieved by variety Gaddissa. The nutritional composition of sweet potato which are important in meeting human nutritional needs including carbohydrates, fibers, carotenes, thiamine, riboflavin, niacin, potassium, zinc, calcium, iron, vitamins $\mathrm{A}$ and $\mathrm{C}$ and high quality protein. Sweet potato particularly provides energy in the human diet in the form of carbohydrates (Adepoju and Adejumo, 2015). Vitamin A deficiency for instance is widespread in young children especially in the developing world and is a leading cause of early childhood death. It is also generally recognized that the insufficient energy density of complementary foods is an etiological factor of protein-energy malnutrition in young children. Also, Rose and Vasanthakaalam, (2011) who found that the orange flesh sweet potatoes are high in carotenoids and $\beta$ carotene. Also, who reported that the consumption of orange flesh sweet potato roots can provide sustainable vitamin $A$, which plays a major role in preventing night blindness). Beta carotene serves as an important nutritional component in foods as a major precursor of vitamin A and it provides a pleasant yellow to orange color to foods.

The present investigation was carried out production of soup from the three varieties of sweet potato (Min6/96) hybrid recorded in Hort. Res. Department since (2005) and two local varieties in Egypt (L.var B and L.var C). Therefore presents findings on possible production of soup from the three varieties of sweet potato commonly found in Egypt. 


\section{MATERIALS AND METHODS}

The present investigation was carried out at the Experimental Farm of Hor. Res. Station, El-Kanater El-Khyria. Kalubia Governorate, Egypt, during the successive season 2014 and 2015. Sweet potato varieties used in this study (min6/96) hybrid recorded in Hort. Res. Department since (2005) and two local varieties in Egypt (L.var B and L.var C). A Randomized complete block design with three replicates was used in all evaluation experiments. Each plot contained 18 plants spaced at $70 \times 30 \mathrm{~cm}$ irrigation were practiced as used with commercial production of sweet potato. The transplants of sweet potato varieties were transplanting of May $7^{\text {th }}$ both seasons of study. The harvest was done at full maturity (about 150 days after transplanting).

\section{plant characters}

Number of branches/plant, stem length of the main stem $(\mathrm{cm})$ (from ground level to terminal) bud of longest vegetative, number of leaves on vin main stem, length of neck leaf and weight of $\mathrm{kg}$. These characters were determined for three plants in each replicate in all seasons (110 days after transplanting).

\section{Yield and its component:-}

Total yield of tuber roots per plant, average number of tuber roots/plant, and average weight of one storage root ( $\mathrm{gm})$, average length and diameter of tuber root $(\mathrm{cm})$ were determined. Tuber roots were randomly chosen from each treatment to determine average length and diameter of tuber roots.

\section{Materials :-}

Lentil, whole wheat, dry onion, skimmed milk, fresh tomato, salt and sunflower oil were obtained from the local market at Giza, Egypt. Pepsin, pancreatin, a-amylase and lipase were purchased from Sigma- Aldrich Chemical Co. (St. Louis, USA) and bile extracts from Win Lab Laboratory chemicals reagents (Mumbai, India).

\section{Technological processes}

\section{- Preparation of sweet potato}

Sweet potato varieties were washed in running tap water to remove any adhering soil, dirt and dust, followed by draining the water. The tubers roots were dried at room temperature $\left(30-32^{\circ} \mathrm{C}\right)$. Then the sweet potato was cut into thin slices of 2-3 mm thickness and steam blanched for five minutes. Finally, the sweet potato was dried in an electric oven at $50^{\circ} \mathrm{c}$ for $12 \mathrm{hr}$.

\section{- Preparation of wheat}

Whole wheat grains was cleaned, weighted, washed and soaked in water at ambient temperature with a ratio of $1: 3(\mathrm{v} / \mathrm{v})$ for $12 \mathrm{~h}$. Wheat seeds were cooked 
individually by boiling with sufficient amounts of water, till they became tender and cooked. Finally, the cooked wheat was dried in an electric oven at $55^{\circ} \mathrm{c}$ for $12 \mathrm{hr}$.

\section{- Preparation of lentil}

Lentil was washed in water to remove dust and boiling with sufficient amounts of water, till they became tender and cooked. Finally, the cooked lentil was dried in an electric oven at $55^{\circ} \mathrm{c}$ for $12 \mathrm{hr}$.

\section{- Preparation of tomato}

After washing with water, the tomato was cut into thin slices of 2-3 mm thickness and steam blanched for three minutes. Finally, the tomato was dried in an electric oven at $50^{\circ} \mathrm{C}$ for $12 \mathrm{hr}$.

\section{- Preparation of soup formulas}

After complete drying, all samples were milled with a laboratory mill (MLW, Type: Sk1, watt100, West Germany), passed through 150 mesh sieve to obtain fine flour of uniform size. The formulation of soup is generally based on the small children and elderly consumes an average of $100 \mathrm{~g}$ per day. The prepared from local V.B (orange sweet potato), local V.C (white sweet potato) and new V. Min.6 (yellow sweet potato). The blends were packed in polythene bag and stored at room temperature $\left(32-37^{\circ} \mathrm{C}\right)$. Ten formulas were used as shown in Table (1).

Table 1. Different formulas of soup $(\mathrm{g} / 100 \mathrm{~g})$.

\begin{tabular}{|c|c|c|c|c|c|c|c|c|c|c|}
\hline Ingredients & $\begin{array}{c}\text { Whole } \\
\text { wheat }\end{array}$ & Lentil & $\begin{array}{c}\text { Skimmed } \\
\text { milk }\end{array}$ & $\begin{array}{c}\text { White } \\
\text { Sweet } \\
\text { potato }\end{array}$ & $\begin{array}{c}\text { Yellow } \\
\text { Sweet } \\
\text { potato }\end{array}$ & $\begin{array}{c}\text { Orange } \\
\text { sweet } \\
\text { potato }\end{array}$ & $\begin{array}{c}\text { Tomato } \\
\text { powder }\end{array}$ & $\begin{array}{c}\text { Onion } \\
\text { powder }\end{array}$ & Oil & Salt \\
\hline Control & 58 & 20 & 10 & & & & 4 & 2 & 4 & 2 \\
\hline WSPS 20 & 38 & 20 & 10 & 20 & -- & -- & 4 & 2 & 4 & 2 \\
\hline WSPS 25 & 33 & 20 & 10 & 25 & -- & -- & 4 & 2 & 4 & 2 \\
\hline WSPS 30 & 28 & 20 & 10 & 30 & -- & -- & 4 & 2 & 4 & 2 \\
\hline YSPS 20 & 38 & 20 & 10 & -- & 20 & -- & 4 & 2 & 4 & 2 \\
\hline YSPS 25 & 33 & 20 & 10 & -- & 25 & -- & 4 & 2 & 4 & 2 \\
\hline YSPS 30 & 28 & 20 & 10 & -- & 30 & -- & 4 & 2 & 4 & 2 \\
\hline OSPS 20 & 38 & 20 & 10 & -- & -- & 20 & 4 & 2 & 4 & 2 \\
\hline OSPS 25 & 33 & 20 & 10 & -- & -- & 25 & 4 & 2 & 4 & 2 \\
\hline OSPS 30 & 28 & 20 & 10 & -- & -- & 30 & 4 & 2 & 4 & 2 \\
\hline
\end{tabular}

WSPS20 $=20 \%$ White Sweet Potato, WSPS25 $=25 \%$ White Sweet Potato, WSPS30 $=30 \%$ White Sweet Potato, YSPS20 $=20 \%$ Yellow Sweet Potato, YSPS25 $=25 \%$ Yellow Sweet Potato, YSPS30 $=30 \%$ Yellow Sweet Potato OSPS $20=20 \%$ Orange Sweet Potato, OSPS $20=20 \%$ Orange Sweet Potato and OSPS $30=$ $30 \%$ Orange Sweet Potato. 


\section{Chemical analysis:-}

moisture, fat, protein, fiber and ash of the tested samples were determined and total carbohydrates, calculated by difference according to A.O.A.C, (2012), thus: Total Carbohydrate $=100-$ (\%Moisture $+\%$ Fat $+\%$ Ash $+\%$ fiber $+\%$ protein $)$.

Physical properties: The foam capacity was determined by the method of Coffman and Garcia, (1977). Water absorption index (WAI) and water solubility index (WSI) were determined in duplicate following the method described by Anderson,(1982). Weight of sediment (WAI) and weight of dry solids (WSI) were calculated using following equations: WAI $=$ weight of sediment $/$ weight of dry solids WSI $=$ weight of dissolved solids in supernatant $\times 100 /$ weight of dry solids. The bulk density $(\mathrm{g} / \mathrm{ml})$ was calculated as weight of flour (g) divided by flour volume (ml) (A.O.A.C, 2012).

The $\mathrm{pH}$ of the soup samples was determine by mixing $10 \mathrm{~g}$ of the samples with $25 \mathrm{ml}$ of distilled water, stirring thoroughly and measured with a $\mathrm{pH}$ meter (Hanna Instruments, Model 18521) at $20^{\circ} \mathrm{C}$ (A.O.A.C, 2012).

\section{Determination of amino acids}

Amino acids were determined by using HPLC-PICO-TAG method according to the method of described by A.O.A.C, (2012). Tryptophan in the tested samples was determined according to Albert et al., (1978).

\section{Nutritional quality}

Nutritional qualities of the materials were determined on the basis of the amino acid profiles. Essential amino acid index (EAAI) and nutritional index (\%) in relation to amino acid requirements of whole egg protein (Valine, 6.6; Methionine+ Cystine, 5.7; Isoleucine, 5.4; leucine, 8.6; Phenylalanine+Tyrosine, 9.3; Lysine, 7.0; Threonine, 4.7, Histedine,1.2 and Tryptophan,2.7) (Shils et al., 1998) were determined as described by Oser, (1959) as follows:

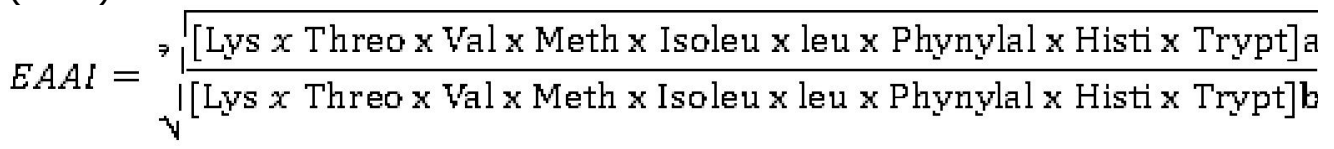

Where $a$ : refers to the sample protein and $b$ : refers to the standard protein (egg or casein), respectively. Nutritional index of the food samples were calculated using the following equation:

Nutritional index $(\%)=\frac{\text { EAAI } x \% \text { protein }}{100}$

The protein efficiency ratio (PER) value was calculated from their amino acid composition based on the equation developed by Alsmeyer et al., (1974) as given 
below: PER $=-1.816+0.435 \times$ Met $+0.780 \times$ Leu $+0.211 \times$ His- $0.944 \times$ Tyr. Biological value was calculated according to Oser, (1959) using the following equation: $B V=1.09 \times$ Essential amino acid index (EAAI) -11.73 . The in vitro protein digestibility of the samples was determined by enzymatic method according to Monjul and John, (1991). In vitro starch digestibility (IVSD) of soup samples was determined by Englyst et al., (1996). Total sugars was determined according to Somogyi, (1952). The total carotenoid and beta ( $($ ) -carotene contents were determined by Okonkwo, (2009). The bioavailability of $\beta$ - carotene was determined by in vitro digestion method as described by Garrett et al., (1999).

\section{Sensory evaluation}

To produce $100 \mathrm{gm}$ of the prepared soup diet, water (drinking water was boiled for 5 minutes) was added in quantity that gives the desired consistency of final product. $85 \mathrm{ml}$ water was added to $15 \mathrm{~g}$ of the formula in a bowl to produce $100 \mathrm{gm}$ of the soup. The soup blends were evaluated for their organoleptic characteristics: Color (10), odor (10), texture (10), appearance (10), taste (10) and overall acceptability (50). The judges included the professors and senior research scholars of Food Technology Research Institute (FTRI) as suggested by Idowu et al., (2013).

\section{Statistical analysis}

All data obtained during both seasons were subjected to statistical analyses and least significant difference (L.S.D. at 0.05 level). Analysis of variance was used to compare between means by Duncan multiple range at significance $5 \%$. Means with different letters are significantly different. ANOVA was carried out by Statistical Analysis System (SAS Program, 1996).

\section{RESULTS AND DISCUSSION}

The following Tables ( 2 and 3 ) show the combined data of the two experimental seasons 2014 and 2015, for only one new variety (Min.6) and two local varieties (local vari $B$ and local vari $C$ with regard to some foliage traits and tuber roots characters. Data in Table (2) show that branches per plant has significant differences among new cultivar and local V. B varieties under studies but local V.C was highest value (30.71), while the main stem $(\mathrm{cm})$ the new Min. 6 V. was second high value than other ones. Concerning number of leaves on main stem the new V. Min.6 gives higher value followed by local V.B and the lowest was local V. C. Regarding length of neck leaf the local they were $14.89,26.77$ and 17.33 in new V.min 6, local V.B and local V.C values, respectively, the similar results were obtained by Salem, Afaf (2010). 
Table 2. Evaluation of different varieties of sweet potato during season 2014 and 2015

\begin{tabular}{|c|c|c|c|c|c|}
\hline \multirow{2}{*}{ Characteristics .No. of } & \multicolumn{2}{|c|}{ Number of } & \multicolumn{2}{|c|}{ Average. length of } & \multirow{2}{*}{$\begin{array}{c}\text { Average weight of } \\
\text { vin } \\
\mathrm{kg}\end{array}$} \\
\hline & Branches/plant & $\begin{array}{l}\text { Leaves on } \\
\text { main } \\
\text { stem }\end{array}$ & $\begin{array}{l}\text { Main } \\
\text { stem } \\
(\mathrm{cm})\end{array}$ & $\begin{array}{c}\text { Neck leaf } \\
(\mathrm{cm})\end{array}$ & \\
\hline New V . Min.6 V & 13.55 & 68.44 & 424.11 & 14.89 & 1.40 \\
\hline Local V.B & 13.55 & 49.77 & 350.44 & 26.77 & 1.93 \\
\hline Local V.C & 30.71 & 35.89 & 212.44 & 17.33 & 2.18 \\
\hline LSD 5\% & 2.47 & 3.95 & 18.74 & 3.80 & 0.274 \\
\hline
\end{tabular}

Data presented in Table (3) showed the comparison between the new variety and local varieties. The yield and number of tuber roots per plant were significantly higher in new V. min. 6 than that found in local V.C and local V.B. The yield and number of tuber roots per plant were recorded 2.06 and 7.88, 0.616 and 5.95, 0.80 and 5.98 in new V. min.6, local V.B and local V.C., respectively. Concerning the two traits average length and diameter of roots $(\mathrm{cm})$ data in Table (3) showed that no significant differences between new V. Min 6 and local V.B in this study, it could be recommended as new variety Min. 6 for using in commercial production, which it is the best for most trait under study. These results were in agreement with those obtained by Berhanu and Beniam, (2013) and yahay et al., (2015).

Table 3. Evaluation of different varieties of sweet potato during season 2014 and 2015

\begin{tabular}{|l|l|l|l|l|l|}
\hline \multirow{2}{*}{ Characteristics } & \multicolumn{2}{|c|}{ Weight of } & \multicolumn{2}{c|}{ Average of tuber root } & \multirow{2}{*}{$\begin{array}{c}\text { No.of tuber } \\
\text { roots/plant }\end{array}$} \\
\cline { 2 - 5 } & $\begin{array}{c}\text { Total } \\
\text { yield/plant Kg } \\
\text { Of (tuber roots) }\end{array}$ & $\begin{array}{c}\text { On storage } \\
\text { tuber root } \\
(\mathrm{gm})\end{array}$ & $\begin{array}{c}\text { Length } \\
(\mathrm{cm})\end{array}$ & $\begin{array}{c}\text { Diameter } \\
(\mathrm{cm})\end{array}$ & \\
\hline New Min.6 V & 2.06 & 264.25 & 22.70 & 7.19 & 7.88 \\
\hline Local V.B & 0.616 & 186.87 & 21.63 & 7.03 & 5.95 \\
\hline Local V.C & 0.800 & 249.34 & 15.80 & 6.08 & 5.98 \\
\hline LSD 5\% & 0.26 & 5.145 & 3.64 & 0.323 & 0.529 \\
\hline
\end{tabular}

Data presented in Table (4) shows that fat, protein and fiber were significantly higher in local V.B (orange sweet potato) than that found in local V.C (white sweet potato) and new V. min.6 (yellow sweet potato). While, there were no significant difference between all sweet potato genotypes in ash content. Local V.C contained the highest amounts of total carbohydrate compared to that found in local V.B and new V. min 6. The results were agreement with Adepoju and Adejumo, (2015). 
Table 4. Chemical composition for tuber roots of sweet potato varieties $(\mathrm{g} / 100 \mathrm{~g})$ on fresh weight basis

\begin{tabular}{|l|c|c|c|c|c|c|}
\hline \multicolumn{1}{|c|}{ Varieties } & Moisture & Fat & Protein & Fiber & Ash & T.C* \\
\hline $\begin{array}{l}\text { NewV. Min.6 } \\
\text { (yellow sweet } \\
\text { potato) }\end{array}$ & $62.52^{\mathrm{a}} \pm 0.0251$ & $0.436^{\mathrm{b}} \pm 0.0152$ & $2.6^{\mathrm{b}} \pm 0.10$ & $1.58^{\mathrm{b}} \pm 0.0264$ & $1.16^{\mathrm{a}} \pm 0.02$ & $31.70^{\mathrm{b}} \pm 0.0152$ \\
\hline $\begin{array}{l}\text { Local V.B } \\
\text { (orange sweet } \\
\text { potato) }\end{array}$ & $60.60^{\mathrm{b}} \pm 0.158$ & $0.72^{\mathrm{a}} \pm 0.0208$ & $3.76^{\mathrm{a}} \pm 0.152$ & $2.11^{\mathrm{a}} \pm 0.0152$ & $0.56^{\mathrm{b}} \pm 0.052$ & $32.25^{\mathrm{b}} \pm 0.0152$ \\
\hline $\begin{array}{l}\text { Local V.C } \\
\text { (white sweet } \\
\text { potato) }\end{array}$ & $54.82^{\mathrm{c}} \pm 0.0655$ & $0.326^{\mathrm{c}} \pm 0.0208$ & $1.32^{\mathrm{c}} \pm 0.118$ & $1.54^{\mathrm{c}} \pm 0.0152$ & $1.15^{\mathrm{a}} \pm 0.0251$ & $40.84^{\mathrm{a}} \pm 0.0208$ \\
\hline
\end{tabular}

T.C* $=$ Total carbohydrates calculated by difference, each value (average of 3 replicates) within the same column; each value (average of 3 replicates) is followed by the standard deviation .

The result in Table (5) shows that there is no significant difference in the moisture contents of sweet potato varieties. As regards the effect of dehydration process on fat, fiber and carbohydrate content it could be noticed that pronounced increment in all varieties. The apparent increment of this content may be due to the decrement of the moisture materials. Meanwhile a slightly significantly increment of fiber, ash and protein could be obvious as a result of the cooking process. These results were agreement with Adepoju and Adejumo, (2015) they reported that the sweet potato sample boiled unpeeled had the highest value of protein, carbohydrate and low value of fat content in compared with the peeled sweet potato.

Table 5. Chemical composition for tuber roots of sweet potato varieties $(\mathrm{g} / 100 \mathrm{~g})$ on dry weight basis

\begin{tabular}{|l|c|c|c|c|c|c|}
\hline \multicolumn{1}{|c|}{ Varieties } & Moisture & Fat & Protein & Fiber & Ash & T.C* \\
\hline $\begin{array}{l}\text { New V. Min.6 } \\
\text { (yellow sweet } \\
\text { potato) }\end{array}$ & $5.69^{\mathrm{a}} \pm 0.060$ & $0.74^{\mathrm{b}} \pm 0.010$ & $3.63^{\mathrm{b}} \pm 0.026$ & $4.23^{\mathrm{b}} \pm 0.010$ & $3.74^{\mathrm{b}} \pm 0.030$ & $81.97^{\mathrm{b}} \pm 0.0057$ \\
\hline $\begin{array}{l}\text { Local V.B } \\
\text { (orange sweet } \\
\text { potato) }\end{array}$ & $5.81^{\mathrm{a}} \pm 0.057$ & $0.95^{\mathrm{a}} \pm 0.0108$ & $5.76^{\mathrm{a}} \pm 0.055$ & $4.65^{\mathrm{a}} \pm 0.0057$ & $4.97^{\mathrm{a}} \pm 0.0057$ & $77.86^{\mathrm{c}} \pm 0.051$ \\
\hline $\begin{array}{l}\text { Local V.C } \\
\text { (white sweet } \\
\text { potato) }\end{array}$ & $5.56^{\mathrm{a}} \pm 0.057$ & $0.65^{\mathrm{c}} \pm 0.010$ & $2.26^{\mathrm{c}} \pm 0.010$ & $3.43^{\mathrm{c}} \pm 0.0057$ & $2.86^{\mathrm{c}} \pm 0.0152$ & $85.24^{\mathrm{a}} \pm 0.062$ \\
\hline
\end{tabular}

T.C* $=$ Total carbohydrates calculated by difference; each value (average of 3 replicates) within the same column; each value (average of 3 replicates) is followed by the standard deviation

The data in Table (6) show that the total carotenoids and $\beta$-carotene are significantly high in fresh of tuber roots for orange sweet potato (local V.B) (5143.10 and $2426.5 \mu \mathrm{g} / 100 \mathrm{~g}$, respectively), while fresh white sweet potato (local V.C) was significantly the lowest values (4.9 and $2.80 \mu \mathrm{g} / 100 \mathrm{~g}$, respectively). On the other hand, the monitoring of such cooked materials with respect to their components is one of the critical points to identify their 
benefits in final products. Total carotenoid and $\beta$-carotene showed a significant decrement pattern as a result of cooking and dried process in the present study (Table 6). These may be resulted in the starch content in sweet potato was increased of absorption of water caused cooking process. These results agreed with George et al., (2009) who reported that the significant differences $(p<0.05)$ in total carotenoid levels obtained among the fresh sweet potato roots could be attributed to varietal differences.

Table 6 . The contents of total caroteneoid, $\beta$-carotene $(\mu \mathrm{g} / 100 \mathrm{~g})$ and total sugar $\%$ in sweet potato varieties

\begin{tabular}{|c|c|c|c|}
\hline Varieties & $\begin{array}{c}\text { Total carotenoid } \\
(\mu \mathrm{g} / 100 \mathrm{~g})\end{array}$ & $\beta$-carotene $(\mu \mathrm{g} / 100 \mathrm{~g})$ & Total sugar \% \\
\hline Fresh New V. Min.6 & $2608.0^{\mathrm{c}} \pm 0.0663$ & $867.30^{\mathrm{c}} \pm 0.0763$ & $2.24^{\mathrm{e}} \pm 0.0152$ \\
\hline Dried New V. Min.6 & $2105.20^{\mathrm{d}} \pm 0.0563$ & $675.21^{\mathrm{d}} \pm 0.0663$ & $3.36^{\mathrm{c}} \pm 0.0152$ \\
\hline Fresh Local V.B & $5143.10^{\mathrm{a}} \pm 0.0763$ & $2426.5^{\mathrm{a}} \pm 0.052$ & $1.43^{\mathrm{f}} \pm 0.0173$ \\
\hline Dried Local V.B & $4120.20^{\mathrm{b}} \pm 0.0363$ & $2125.61^{\mathrm{b}} \pm 0.0763$ & $5.44^{\mathrm{a}} \pm 0.010$ \\
\hline Fresh Local V.C & $4.90^{\mathrm{e}} \pm 0.0763$ & $2.80^{\mathrm{a}} \pm 0.0763$ & $2.56^{\mathrm{d}} \pm 0.0057$ \\
\hline Dried Local V.C & $1.93^{\mathrm{f}} \pm 0.0463$ & $0.90^{\mathrm{f}} \pm 0.0563$ & $4.75^{\mathrm{b}} \pm 0.0208$ \\
\hline
\end{tabular}

-Each value (an average of three replicates) is followed by the standard deviation.

The same Table appeared that the total sugar was higher in all dried sweet potato than fresh sweet potato varieties. This increment was due to dry processing. The apparent increment of sugar may be due to the decrement of other constituent materials. Meanwhile a slightly significantly increment of sugar could be obvious as a result of the cooking process of sweet potato, agreed with Idowu et al.,(2013).

Table 7. Amino acids content of the tested materials (calculated as $\mathrm{g} / 100 \mathrm{~g}$ protein).

\begin{tabular}{|l|c|c|c|c|c|c|}
\hline Amino acid & $\begin{array}{l}\text { Whole } \\
\text { wheat }\end{array}$ & Lentil & $\begin{array}{l}\text { Skimmed } \\
\text { milk }\end{array}$ & $\begin{array}{l}\text { White } \\
\text { sweet } \\
\text { potato } \\
\text { (V.C) }\end{array}$ & $\begin{array}{l}\text { Yellow sweet } \\
\text { Potato(new) }\end{array}$ & $\begin{array}{l}\text { Orange sweet } \\
\text { potato(V.B) }\end{array}$ \\
\hline Isoleucine & 3.28 & 3.5 & 5.90 & 0.18 & 0.30 & 0.28 \\
Leucine & 6.35 & 6.4 & 9.80 & 0.26 & 0.43 & 0.40 \\
Lysine & 0.44 & 6.3 & 7.30 & 0.17 & 0.30 & 0.26 \\
Methionine & 1.42 & 0.6 & 1.50 & 0.06 & 0.09 & 0.10 \\
Cystine & 1.86 & 1.3 & 2.00 & 0.07 & 0.19 & 0.13 \\
Phenylalanine & 1.58 & 4.1 & 4.00 & 0.27 & 0.42 & 0.41 \\
Tyrosine & 2.85 & 2.3 & 5.10 & 0.13 & 0.30 & 0.30 \\
Threonine & 2.78 & 3.1 & 3.60 & 0.23 & 0.30 & 0.31 \\
Valine & 4.14 & 4.0 & 6.20 & 0.26 & 0.43 & 0.41 \\
Tryptophan & 0.72 & 0.9 & 1.20 & 0.15 & 0.18 & 0.17 \\
Total essential amino acids & 23.42 & 32.5 & 46.60 & 1.78 & 2.94 & 2.77 \\
Aspartic acid & & & & & & \\
Serine & 4.83 & 9.9 & 7.20 & 0.68 & 1.87 & 1.03 \\
Glutamic & 2.60 & 4.3 & 5.10 & 0.21 & 0.27 & 0.28 \\
Proline & 25.78 & 14.0 & 9.40 & 0.48 & 0.72 & 0.62 \\
Glycine & 2.48 & 3.5 & 11.60 & 0.14 & 0.26 & 0.23 \\
Alanine & 4.88 & 3.5 & 1.50 & 0.17 & 0.28 & 0.26 \\
Arginine & 3.66 & 3.7 & 3.20 & 0.23 & 0.43 & 0.42 \\
Histidine & 3.09 & 6.9 & 3.90 & 0.19 & 0.34 & 0.29 \\
Total amino acids & 6.12 & 2.1 & 4.00 & 0.09 & 0.18 & 0.15 \\
Pon & 76.86 & 82.0 & 92.50 & 3.97 & 6.56 & 6.05 \\
\hline
\end{tabular}


From the data in Table (7), it could be noticed that the yellow sweet potato had higher EAA and nonessential amino acids when compared with white and orange sweet potato varieties. Moreover, Whole wheat and skimmed milk powder were higher in total sulfur amino acids contents (methionine and cystine) than the lentil and sweet potato varieties. We have produced high protein sweet potato soups using two protein sources like skimmed milk and lentil each having specific functional attributes as well.

\section{Nutritional quality of the tested soup}

Data presented in Table (8) showed the mathematically amino acids content of $100 \mathrm{gm}$ of the produced soup. Mixing whole wheat, skimmed milk and lentil with sweet potato varieties improved the amino acid profile. All amino acids were increased compared to amino acids as shown in Table 7 which reported that new V.Min6 the best of amino acids content than the local V. (B and $C$ ) in this study. According to the previous presented data, it could be noticed that, the total essential amino acids increased with increasing the replacement the level of whole wheat and increasing the total nonessential amino acids percentage. Amino acids levels were in the range of those reported in the literature (Ijarotimi, 2012). The highest essential amino acids content was noticed in the tested blends soup than that found in the pattern recommended by FAO/WHO (2007).

Table 8. Amino acids content of the sweet potato soup blends (calculated as g/100 protein).

\begin{tabular}{|c|c|c|c|c|c|c|c|c|c|c|c|}
\hline Amino acid & control & WSPS20 & WSPS25 & WSPS30 & YSPS20 & YSPS25 & YSPS30 & OSPS20 & OSPS25 & OSPS30 & $\begin{array}{l}\text { FAO /WHO } \\
\text { Child (Adult) }\end{array}$ \\
\hline Isoleucine & 2.50 & & 3.60 & & 3.91 & 3.64 & & & 3.64 & 3.49 & \\
\hline Leucine & 7.10 & 3.80 & 3.00 & 3.50 & 707 & 6800 & 3.61 & 3.69 & $\begin{array}{l}3.04 \\
6.55\end{array}$ & 6.10 & \\
\hline Lysine & 3.93 & 6.99 & 0.84 & 6.72 & 7.01 & 504 & 6.60 & 6.68 & 0.55 & 6.63 & \\
\hline Methionine & 4.18 & 4.09 & 4.20 & 4.60 & 4.33 & 5.04 & 5.32 & 4.08 & 3.27 & 3.80 & \\
\hline Cystine & 1.75 & 4.16 & 4.36 & 4.36 & 4.12 & 4.06 & 4.01 & 3.89 & 3.91 & 1.91 & \\
\hline Phenylalanine & 2.93 & 1.62 & 1.57 & 1.36 & 1.80 & 1.68 & 1.49 & 2.17 & 2.09 & 2.80 & \\
\hline Phenylalaning & $\begin{array}{l}2.93 \\
3.25\end{array}$ & 3.03 & 3.01 & 2.88 & 3.07 & 3.01 & 2.90 & 2.83 & 2.83 & 2.00 & $3(3)$ \\
\hline Tyrosing & 3.25 & 3.17 & 3.08 & 3.06 & 3.14 & 3.01 & 2.90 & 2.96 & 2.90 & 273 & $6(50)$ \\
\hline Threonine & 3.12 & 303 & 2.94 & 3.09 & 3.00 & 2.87 & 2.94 & 2.90 & 2.77 & 2.13 & $6(5.9)$ \\
\hline Valine & 4.60 & 3.00 & 4.38 & $\begin{array}{l}2.94 \\
4.30\end{array}$ & 4.47 & 4.27 & 2.83 & 3.95 & 4.12 & 4.04 & $4.8(4.5)$ \\
\hline Tryptophan & 0.87 & 4.51 & 0.82 & 4.34 & 0.85 & 0.84 & 4.18 & 4.22 & 0.86 & 0.85 & \\
\hline Total essentia & 34.29 & 0.83 & 34.72 & $\begin{array}{r}0.81 \\
33.40\end{array}$ & 35.76 & 35.22 & 0.83 & 0.87 & 37.57 & 35.05 & $2.3(1.6)$ \\
\hline amino acids & & JJ.L4 & & 50.49 & & & 37.01 & 30.94 & & & $4.1(3.8)$ \\
\hline Aspartic acid & 7.25 & & 720 & & 7.26 & 7.08 & & & 676 & 6.71 & $2.5(2.3)$ \\
\hline Serine & 3.75 & 7.28 & 3.60 & 6.36 & 3.70 & 3.57 & 7.02 & 6.86 & $\begin{array}{l}0.10 \\
3.44\end{array}$ & 3.42 & $2.9(3.9)$ \\
\hline Glutamid & 18.93 & 3.74 & 1580 & 3.50 & 1691 & 15.42 & 3.54 & 3.82 & 14.86 & 13.97 & $0.66(0.6)$ \\
\hline Proline & 4.93 & 16.73 & $\begin{array}{r}13.00 \\
5.30\end{array}$ & 15.26 & $\begin{array}{r}10.91 \\
5.11\end{array}$ & $\begin{array}{r}13.44 \\
4.97\end{array}$ & 14.40 & 16.42 & $\begin{array}{r}14.80 \\
470\end{array}$ & 4.79 & $26.10(25.60)$ \\
\hline Glycine & 3.75 & 5.48 & 3.16 & 5.26 & 3.19 & 3.08 & 4.96 & 5.07 & $\begin{array}{l}4.19 \\
2.97\end{array}$ & 2.87 & \\
\hline Alanine & 3.68 & 3.38 & 3.37 & 3.08 & 3.42 & 3.29 & 2.90 & 3.49 & 3.17 & 3.08 & \\
\hline Arginine & 4.68 & 3.46 & 4.80 & 3.38 & $\begin{array}{l}3.74 \\
4.68\end{array}$ & 4.55 & 3.19 & 3.75 & $\begin{array}{l}.17 \\
339\end{array}$ & 4.31 & \\
\hline Histidine & 4.20 & 5.03 & 3.66 & 4.73 & 3.84 & 3.57 & 4.47 & 4.74 & 3.60 & 3.21 & \\
\hline Total amind & 85.40 & 3.88 & 81.66 & $\begin{array}{r}3.53 \\
78.50\end{array}$ & 83.96 & 80.75 & 3.33 & 3.62 & 80.55 & 77.41 & \\
\hline & & & & & & & & 83.11 & & & \\
\hline
\end{tabular}

WSPS20 $=20 \%$ White Sweet Potato, WSPS25 $=25 \%$ White Sweet Potato, WSPS30 $=30 \%$ White Sweet Potato, YSPS20 $=20 \%$ Yellow Sweet Potato, YSPS25 $=25 \%$ Yellow Sweet Potato, YSPS30 $=30 \%$ Yellow Sweet Potato OSPS 20 $=20 \%$ Orange Sweet Potato , OSPS 20 $20 \%$ Orange Sweet Potato and OSPS 30= 30\% Orange Sweet Potato. Source:FAO /WHO (2007) 
The protein content of tested soup is given in Table 9. The content of protein range from 13.3 to $16.0 \mathrm{~g}$ per $100 \mathrm{~g}$ soup as dry weight. The values of calculated protein efficiency ratio (C-PER) of the soup blends were 2.72 to 3.35 quite satisfactory compared with a standard casein PER of 2.5 (Ijarotimi, 2012) and were higher than the findings reported by Jyothi et al., (2011), who reported that PER of 1.68 and 2.09 for WPC (wheat protein concentrate) fortified sweet potato pasta and defatted soy bean flour-pasta. In general, the protein efficiency ratio below 1.5 implies a protein of low or poor quality, while PER between 1.5 and 2.0 indicates an intermediate protein quality and then PER above 2.0 means protein of high quality (Ijarotimi, 2012). Also, data in Table (9) recorded that the biological values (BV), essential amino acid index (EAAI) and nutritional index (NI) ranged between, 70.07 to $73.63,75.05$ to 78.32 and 9.98 to 12.03 , respectively in the soup blends. This observation shows that consumption of whole wheat meal alone without complement with other proteinbased foods like legumes may not adequately meet the nutritional needs of it consumers. Scientifically, it is well known that a protein-based food material is of good nutritional quality when its biological values (BV) is high (70 to 100\%) and also when the essential amino acid index (EAAI) is above $90 \%$ and to be useful as food when the values is around $80 \%$ and to be inadequate for food material when its EAAI is below 70\% (Oser, 1959). On the other hand, results in Table (9) show that the in vitro starch digestibility (IVSD) of soup blends were higher than that found in control (without sweet potato). These results agreed with Kim et al., (2008) who reported that the reduction in cohesiveness between starch and protein could increase the accessibility of starch to alpha amylase resulting in increased digestibility in the pasta passed more than once through the sheeting rollers. Improvement in starch digestibility could be attributed due to hydrolysis of starch as a result of heat treatments. The higher digestibility of processed flours may be due to comparatively less branching and low molecular weight of the starch constituent fractions. However, earlier workers also reported that cooking improves the digestibility of starch through gelatinization and destruction of antinutrients, agreed with Walter et al., (2001).

Table 9. Nutrient quality of the tested soup

\begin{tabular}{|c|c|c|c|c|c|c|c|}
\hline Soup & \%Protein & PER & BV & EAAI & NI & (IVSD) & IVPD \\
\hline Control & 16.00 & 3.35 & 70.25 & 75.21 & 12.03 & 30 & 74.9 \\
\hline WSPS 20 & 14.16 & 3.27 & 72.47 & 77.25 & 10.93 & 32 & 74.8 \\
\hline WSPS 25 & 13.92 & 3.26 & 70.93 & 75.84 & 10.55 & 34 & 74.0 \\
\hline WSPS 30 & 13.30 & 3.17 & 70.07 & 75.05 & 9.98 & 40 & 74.5 \\
\hline YSPS 20 & 14.31 & 3.33 & 73.63 & 78.32 & 11.20 & 33 & 74.6 \\
\hline YSPS 25 & 14.26 & 3.16 & 71.81 & 76.65 & 10.93 & 36 & 74.4 \\
\hline YSPS 30 & 14.09 & 3.04 & 70.16 & 75.13 & 10.58 & 41 & 73.9 \\
\hline OSPS 20 & 15.16 & 3.05 & 73.20 & 77.92 & 11.81 & 34 & 73.5 \\
\hline OSPS 25 & 14.80 & 2.90 & 71.46 & 76.33 & 11.29 & 37 & 73.4 \\
\hline OSPS 30 & 14.60 & 2.72 & 70.25 & 75.22 & 10.98 & 42 & 73.2 \\
\hline
\end{tabular}


WSPS20 $=20 \%$ White Sweet Potato, WSPS25 $=25 \%$ White Sweet Potato,WSPS30 $=30 \%$ White Sweet Potato, YSPS20 $=20 \%$ Yellow Sweet Potato,YSPS25 $=25 \%$ Yellow Sweet Potato, YSPS30 $=30 \%$ Yellow Sweet Potato OSPS 20 $=20 \%$ Orange Sweet Potato, OSPS 20 $=20 \%$ Orange Sweet Potato and OSPS 30= $30 \%$ Orange Sweet Potato. $\mathrm{PER}=$ Protein efficiency ratio, $\mathrm{BV}=$ Biological value, $\mathrm{EAAI}=$ Essential amino acid index, NI= Nutritional index $($ IVSD),$=$ In Vitro Starch Digestibility (IVSD) and IVPD $=$ In Vitro protein Digestibility

Also, data in Table (9) showed that the in vitro protein digestibility (IVPD in the tested soup ranged from $73.20 \%$ to $74.9 \%$, which were not difference between the soup blends. It was due to the stability proportion of lentil and skimmed milk ingredient in such blends.

Table (10) showed the bioavailability of $\beta$-carotene in different soup, it could be noticed that the control was the lowest when compared to other ones in total $\beta$ carotene. Data in Table (10) recorded that the OSPS blends had higher than YSPS

Table 10. Bioavailability of $\beta$ carotene in vitro for the tested soup $(\mu \mathrm{g} / 100 \mathrm{~g})$

\begin{tabular}{|c|c|c|c|}
\hline \multirow{2}{*}{ Soup } & \multicolumn{3}{|c|}{$\beta$ - carotene } \\
\cline { 2 - 4 } & $\mu \mathrm{g} / 100 \mathrm{~g}$ & $\mu \mathrm{c}$ Bioavailability \\
\cline { 2 - 4 } & 1.60 & 0.50 & $\%$ \\
\hline Control & 1.78 & 0.56 & 31.25 \\
\hline WSPS 20 & 1.82 & 0.60 & 31.46 \\
\hline WSPS 25 & 1.87 & 0.62 & 32.96 \\
\hline WSPS 30 & 136.64 & 90.51 & 33.10 \\
\hline YSPS 20 & 170.40 & 117.20 & 66.23 \\
\hline YSPS 25 & 204.16 & 150.0 & 68.77 \\
\hline YSPS 30 & 426.72 & 320.72 & 73.47 \\
\hline OSPS 20 & 531.40 & 413.20 & 75.15 \\
\hline OSPS 25 & 637.68 & 516.50 & 77.75 \\
\hline OSPS 30 & & & 80.99 \\
\hline
\end{tabular}

WSPS20 $=20 \%$ White Sweet Potato, WSPS25 $=25 \%$ White Sweet Potato, WSPS30 $=30 \%$ White Sweet Potato, YSPS20 $=20 \%$ Yellow Sweet Potato,YSPS25 $=25 \%$ Yellow Sweet Potato,YSPS30 $=30 \%$ Yellow Sweet Potato OSPS 20 $=20 \%$ Orange Sweet Potato, OSPS $20=20 \%$ Orange Sweet Potato and OSPS $30=$ $30 \%$ Orange Sweet Potato.

blends of total $\beta$ - carotene content, but the YSPS blends had a higher percent of $\beta$ carotene than WSPS and control blends. These results are a line with Rose and Vasanthakaalam, (2011). The results in Table(10) indicate that the bioavailability of $\beta$ -carotene in OSPS 20, OSPS 25 and OSPS 30 soup blends were higher than that found in soup from yellow sweet potato (YSPS), white sweet potato (WSPS) and without sweet potato (control). The soup prepared from yellow sweet potato had a high percent of $\beta$-carotene bioavailability ( 66.23 to $73.47 \%$ ) when compared to soup prepared from white sweet potato and control soup ( 31.46 to $33.10 \%$ and $31.25 \%$, respectively). 
Table 11. Functional properties of the tested soup

\begin{tabular}{|c|c|c|c|c|c|}
\hline Soup & $\begin{array}{c}\text { Foaming } \\
\text { capacity }(\%)\end{array}$ & $\begin{array}{c}\text { Water absorption } \\
\text { index(ggel/gsample) }\end{array}$ & $\begin{array}{c}\text { Water solubility } \\
\text { index }(\%)\end{array}$ & $\begin{array}{c}\text { Bulk density } \\
\mathrm{g} / \mathrm{ml}\end{array}$ & $\mathrm{pH}$ \\
\hline Control & $5.6^{\mathrm{c}} \pm 0.087$ & $2.78^{\mathrm{g}} \pm 0.01$ & $5.63^{\mathrm{i}} \pm 0.019$ & $0.43^{\mathrm{b}} \pm 0.057$ & $5.70^{\mathrm{a}} \pm 0.10$ \\
\hline WSPS 20 & $7.50^{\mathrm{b}} \pm 0.097$ & $3.88^{\mathrm{f}} \pm 0.01$ & $9.38^{\mathrm{h}} \pm 0.11$ & $0.54^{\mathrm{a}} \pm 0.057$ & $5.83^{\mathrm{d}} \pm 0.057$ \\
\hline WSPS 25 & $8.0^{\mathrm{a}} \pm 0.057$ & $4.45^{\mathrm{d}} \pm 0.01$ & $10.92^{\mathrm{f}} \pm 0.11$ & $0.54^{\mathrm{a}} \pm 0.057$ & $6.26^{\mathrm{a}} \pm 0.057$ \\
\hline WSPS 30 & $8.06^{\mathrm{a}} \pm 0.077$ & $5.13^{\mathrm{c}} \pm 0.015$ & $11.54^{\mathrm{e}} \pm 0.017$ & $0.54^{\mathrm{a}} \pm 0.057$ & $6.13^{\mathrm{c}} \pm 0.0577$ \\
\hline YSPS 20 & $7.50^{\mathrm{b}} \pm 0.047$ & $4.08^{\mathrm{e}} \pm 0.01$ & $10.56^{\mathrm{g}} \pm 0.016$ & $0.54^{\mathrm{a}} \pm 0.057$ & $6.23^{\mathrm{ab}} \pm 0.057$ \\
\hline YSPS 25 & $8.00^{\mathrm{a}} \pm 0.067$ & $5.19^{\mathrm{c}} \pm 0.015$ & $11.83^{\mathrm{d}} \pm 0.24$ & $0.54^{\mathrm{a}} \pm 0.057$ & $6.16^{\mathrm{abc}} \pm 0.057$ \\
\hline YSPS 30 & $8.05^{\mathrm{a}} \pm 0.057$ & $6.85^{\mathrm{b}} \pm 0.01$ & $13.22^{\mathrm{c}} \pm 0.0025$ & $0.54^{\mathrm{a}} \pm 0.057$ & $6.26^{\mathrm{a}} \pm 0.050$ \\
\hline OSPS 20 & $7.50^{\mathrm{b}} \pm 0.087$ & $5.18^{\mathrm{e}} \pm 0.020$ & $11.26^{\mathrm{f}} \pm 0.027$ & $0.54^{\mathrm{a}} \pm 0.057$ & $6.06^{\mathrm{c}} \pm 0.057$ \\
\hline OSPS 25 & $8.00^{\mathrm{a}} \pm 0.057$ & $6.67^{\mathrm{b}} \pm 0.017$ & $13.59^{\mathrm{b}} \pm 0.36$ & $0.54^{\mathrm{a}} \pm 0.057$ & $6.16^{\mathrm{abc}} \pm 0.057$ \\
\hline OSPS 30 & $8.05^{\mathrm{a}} \pm 0.067$ & $7.84^{\mathrm{a}} \pm 0.0152$ & $15.03^{\mathrm{a}} \pm 0.006$ & $0.54^{\mathrm{a}} \pm 0.057$ & $6.10^{\mathrm{c}} \pm 0.10$ \\
\hline
\end{tabular}

Each value (average of 3 replicates) within the same column, each value is followed by the standard deviation; WSPS20 $=20 \%$ White Sweet Potato,WSPS25 $=25 \%$ White Sweet Potato,WSPS30 $=30 \%$ White Sweet Potato, YSPS20 $=20 \%$ Yellow Sweet Potato,YSPS25 $=25 \%$ Yellow Sweet Potato, YSPS30 $=30 \%$ Yellow Sweet Potato OSPS $20=20 \%$ Orange Sweet Potato, OSPS $20=20 \%$ Orange Sweet Potato and OSPS $30=30 \%$ Orange Sweet Potato

Data presented in Table (11) show that there were few significant changes in impact of all the tested soups under investigation on foaming capacity. Foaming capacity\% was increased as a result of sweet potato addition compared with control (without sweet potato). Data presented in Table (11) show also that the water absorption index (WAI) is a term which describes the ability of dried soup to absorb or take in water during preparation. The data showed that control sample had the lowest value ( $2.78 \mathrm{~g} \mathrm{gel} / \mathrm{g}$ sample) compared to WSPS $30 \%$ (5.13 g gel $/ \mathrm{g}$ sample), YSPS $30 \%$ (6.85 g gel $/ \mathrm{g}$ sample) and OSPS $30 \%(7.84 \mathrm{~g} \mathrm{gel} / \mathrm{g}$ sample). The highest values of water absorption capacity recorded for the soup from sweet potatoes may be due to the high polar amino acid residue of protein having affinity for molecule of water. The addition of $20-30 \%$ of sweet potato to soup resulted significant different in terms of WAI for soup. This might be due to the more damaged starch present in sweet potato and hold more water. Results in Table 11 shows that WSI of soup blends increased with increasing addition of sweet potato flour to soup. The WSI of soup blends was significantly different $(p<0.05)$ with the addition $30 \%$ of orange sweet potato flour for formulation than other ones. These results were agreement with Grabowski et al., (2006) who reported that the solubility index of dried sweet potato powder increased and its water holding capacity reduced. Bulk density signifies the behavior of a product in dry mixes and is an important parameter that can determine the packaging requirement of a product. Bulk density of the tested soup was measured between 0.43 to $0.54 \mathrm{~g} / \mathrm{ml}$. The bulk density of the tested soups was not significantly different between the addition of 20, 25 and $30 \%$ of orange or yellow or white sweet potato flour at soup contents. Nutritionally, loose bulk density promotes easy digestibility of food products, particularly among children with immature digestive 
system (Ijarotimi, 2012). The pH value was measured between 5.70 to 6.26 for all the soup blends. The higher acidity value was due to the added tomato in the soup.

The data obtained for the sensory evaluation of soup prepared from the various sweet potato are presented in Table (12). In the attribute of color, the results indicate that the OSPS $30 \%$ had the highest mean score of 9.53 , while the lowest score (8.45) was recorded for the control. Statistical analysis showed that the no significant difference in odor, texture and taste among different treatments, while the lowest score (6.54) was recorded for the control in the taste. Appearance attribute of the tested soup showed that WSPS $20 \%$, WSPS $25 \%$, YSPS $30 \%$, OSPS $20 \%$, OSPS $25 \%$ and OSPS $30 \%$ show no inter insignificant differences. On the other hand, WSPS 30\% and control showed the lowest score of appearance attribute and there were statistically difference compared to the other tested soup. Overall-acceptability seemed to no significant difference among the tested soup samples except control, which recorded the lowest value of overall-acceptability. In general, the tested soup blends seemed to be more preferable soup, due to it showed the highest degree of consumer acceptability with respect to all organoleptic properties. These results are in agreement with that found by Idowu et al., (2013).

Table 12. Organoleptic characteristics of the manufactured soup.

\begin{tabular}{|c|l|l|l|l|l|l|}
\hline Soup & \multicolumn{1}{|c|}{$\begin{array}{c}\text { Color } \\
(10)\end{array}$} & $\begin{array}{c}\text { Odor } \\
(10)\end{array}$ & $\begin{array}{c}\text { Texture } \\
(10)\end{array}$ & $\begin{array}{c}\text { Appearance } \\
(10)\end{array}$ & $\begin{array}{c}\text { Taste } \\
(10)\end{array}$ & $\begin{array}{c}\text { Overall- } \\
\text { acceptability } \\
(50)\end{array}$ \\
\hline control & $8.45 \mathrm{~b} \pm 0.32$ & $8.63^{\mathrm{a}} \pm 0.5$ & $9.10^{\mathrm{a}} \pm 0.6$ & $8.09^{\mathrm{b}} \pm 0.831$ & $6.54^{\mathrm{b}} \pm 0.35$ & $40.27^{\mathrm{a}} \pm 3.16$ \\
\hline WSPS 20 & $9.09^{\mathrm{ab}} \pm 0.32$ & $8.63^{\mathrm{a}} \pm 0.9$ & $8.63^{\mathrm{a}} \pm 0.92$ & $8.54^{a^{\mathrm{bc}} \pm 1.12}$ & $8.18^{\mathrm{a}} \pm 0.98$ & $43.7^{\mathrm{ab}} \pm 3.27$ \\
\hline WSPS 25 & $9.09^{\mathrm{ab}} \pm 0.32$ & $8.72^{\mathrm{a}} \pm 1.27$ & $8.72^{\mathrm{a}} \pm 1.27$ & $8.72^{\mathrm{a}} \pm 1.19$ & $8.45^{\mathrm{a}} \pm 1.12$ & $43.7^{\mathrm{ab}} \pm 3.72$ \\
\hline WSPS 30 & $9.09^{9^{\mathrm{ab}} \pm 0.32}$ & $8.9^{\mathrm{a}} \pm 0.54$ & $8.9^{\mathrm{a}} \pm 0.53$ & $8.27^{\circ} \pm 1.19$ & $8.54^{\mathrm{a}} \pm 0.8 .3$ & $42.27^{\mathrm{ab}} \pm 4.41$ \\
\hline YSPS 20 & $9.18^{\mathrm{ab}} \pm 0.32$ & $8.81^{\mathrm{a}} \pm 1.07$ & $8.81^{\mathrm{a}} \pm 1.07$ & $9.0^{\mathrm{ab}} \pm 0.77$ & $8.90^{\mathrm{a}} \pm 0.70$ & $43.27^{\mathrm{ab}} \pm 4.82$ \\
\hline YSPS 25 & $9.27^{\mathrm{ab}} \pm 0.97$ & $8.81^{\mathrm{a}} \pm 0.87$ & $8.81^{\mathrm{a}} \pm 0.87$ & $8.45 b^{\mathrm{c}} \pm 1.03$ & $9.0^{\mathrm{a}} \pm 0.77$ & $44.27^{\mathrm{a}} \pm 2.93$ \\
\hline YSPS 30 & $9.26^{\mathrm{ab}} \pm 0.527$ & $9.0^{\mathrm{a}} \pm 0.77$ & $8.9^{\mathrm{a}} \pm 0.53$ & $8.81^{\mathrm{abc}} \pm 0.78$ & $9.0^{\mathrm{a}} \pm 0.63$ & $44.54^{\mathrm{a}} \pm 2.54$ \\
\hline OSPS 20 & $9.30^{\mathrm{ab}} \pm 0.32$ & $9.0^{\mathrm{a}} \pm 0.94$ & $8.81^{\mathrm{a}} \pm 0.87$ & $8.82^{\mathrm{abc}} \pm 0.87$ & $8.54^{\mathrm{a}} \pm 1.21$ & $44.45^{\mathrm{a}} \pm 4.11$ \\
\hline OSPS 25 & $9.36^{\mathrm{ab}} \pm 0.67$ & $8.9^{\mathrm{a}} \pm 0.90$ & $8.8^{\mathrm{a}} \pm 0.87$ & $8.81^{\mathrm{abc}} \pm 0.83$ & $8.72^{\mathrm{a}} \pm 1.27$ & $44.54^{\mathrm{a}} \pm 4.05$ \\
\hline OSPS 30 & $9.53^{\mathrm{a}} \pm 0.66$ & $8.90^{\mathrm{a}} \pm 1.13$ & $8.90^{\mathrm{a}} \pm 0.70$ & $8.9^{\mathrm{abc}} \pm 0.70$ & $8.72^{\mathrm{a}} \pm 0.90$ & $45.091^{\mathrm{a}} \pm 4.11$ \\
\hline
\end{tabular}

Each value (average of 10 replicates) within the same column, each value is followed by the standard deviation.

WSPS20 $=20 \%$ White Sweet Potato, WSPS25 $=25 \%$ White Sweet Potato,WSPS30 $=30 \%$ White Sweet Potato, YSPS20 $=20 \%$ Yellow Sweet Potato, YSPS25 $=25 \%$ Yellow Sweet Potato, YSPS30 $=30 \%$ Yellow Sweet Potato OSPS 20 $=20 \%$ Orange Sweet Potato, OSPS $20=20 \%$ Orange Sweet Potato and OSPS 30= $30 \%$ Orange Sweet Potato

\section{CONCLUSION}

Sweet potato can be used to reduce malnutrition in the society consequently increased production, availability and consumption should be encouraged by the appropriate stake holders. In general, the tested soup seemed to be more preferable due to it showed the highest degree consumer acceptable with respect to all organoleptic properties and good source of calorie for vulnerable groups that need high energy density food because of small stomach, such as children and the elderly. Finally, the tested material could be considered as a good tool, in spite of the low cost, to prepare high protein soup with high quality and long shelf life. 


\section{REFERENCES}

1. Adepoju, A. L., and Adejumo, B. A. 2015. Some proximate properties of sweet potato (Ipomoea Batatas $L$ ) As Influenced by cooking methods. Inter. J. of Sci. and Tech. Res., 4(3):146-148

2. Albert,E.; William, M. J. and Francis, G.G. 1978. Protein and amino acids of sweet potato (Ipomoea batatas L). Fractions. J. Agric.Food Chem., 26,(3):699-701

3. Alsmeyer, R.H., Cuningham, M.L. and Happich, M.L. 1974. Equations predict PER from amino acid analysis. Food Tech., 28: 34-38.

4. Anderson, R.A. 1982. Water absorption and solubility and amylograph characteristics of roll-cooked small grain products. Cereal Chem., 59: 265-269.

5. A.O.A.C. 2012. Official Methods of Analysis, AOAC Interenational No.994.12,Chapter $4 p 18-19.19^{\text {th }}$ edition Association of Official Analytical Chemists. Washington, D.C.

6. Berhanu,T.and Beniam,T. 2013. Performance evaluation of improved sweet potato (Ipomoea batatas L.) varieties at gedeozone southern Ethiopia. Int. J. Agric and Agri. R.,6 (14): 116-119

7. Coffman C.W. and Garcia, V.V. 1977. Functional properties and amino acid content of protein isolate from mung bean flour. J. Food Tech., 12: 473-484.

8. Englyst, J. Veenstr, G.J. and Hudson, H. N. 1996. "Measure-ment of Rapidly Available Glucose (RAG) in Plant Foods: A Potential in Vitro Predictor of the Glycaemic Response". Brit. J. of Nuti., 75(3): 327-337. doi:10.1079/BJN19960137

9. FAO/WHO 2007. Food and Agriculture Organization/World Health Organization/United Nations University. Joint FAO/WHO/UNU Expert Consultation on Protein and Amino Acid Requirements in Human Nutrition: Geneva, Switzerland. Protein and amino acid requirements in human nutrition: report of a joint FAO/WHO/UNU expert consultation. World Health Organ Tech Rep Series, No. 935:1-265.

10. George, O.; Ibok, O.; Ellis, W.O. and Harrison, K. D. 2009. Assessment of vitamin A content and sensory attributes of new sweet potato (Ipomoea batatas) genotypes in Ghana. African Journal of Food Science., 3(7):184-192.

11. Grabowski, J.A.;Truong, V.D. and Daubert, C.R. 2006. Spray drying of amylase hydrolyzed sweet potato puree and physicochemical properties of powder. Journal of Food Science, 71: E209 - E217.

12. Idowu, O.A.; Olaoye, O.A.; Sogotemi, C.M. and Ajayi, B. 2013. Quality assessment of flour and amala produced from three varieties of sweet potato (ipomea batatas). International Journal of Food Nutritional Sciences.,2(4 ): 1-9. 
13. Ijarotimi, O. S. 2012. Influence of germination and fermentation on chemical composition, protein quality and physical properties of wheat flour (Triticum aestivum). Journal of Cereals and Oil seeds., 3(3): 35-47.

14. Jyothi, G.; Renjusha, M.; Gourikutty, P.; Moothandassery, S.;Sajeev, S. and Narayan, M. 2011. Nutritional and functional characteristics of protein-fortified pasta from sweet potato. Food and Nutrition Sciences, 2: 944-955.

15. Kim, J. R.; Petrie, L.; Motoi, M. P.; Morgenstern, K. H.; Sulton, S.; Mishra, E. H. J. and Simmons, L. D. 2008. Effect of structural and physico-chemical characteristics of the protein matrix in pasta on in Vitro starch digestibility. Food Biophysics., 3(2): 229-234. doi:10.1007/s11483-008-9066-7

16. Monjul, S. and John, E. 1991. Biochemical changes and in vitro protein digestibility of endosperm of germinating Dolichos lablab. J. Sci. Food Agric, 5:429-438.

17. Mwanga,R. O.; Odongo, M. B.; Niringiye, C.; Alajo, A.; Kigozo, B.; Makumbi, R.; Lemago,B.; Hsumbo, J.; Tumwegamire, S. and yench, C.G. 2009. Naspot 7, Naspot and Naspot,Naspot 100 and Dimabuka Bukulula sweet potato. Hort.Science, 44(3):828-832.

18. Okonkwo, J.C. 2009. Effects of breed and storage duration on the Beta-Carotene content of egg yolk. Pakistan Journal of Nutrition., 8 (10): 1629-1630

19. Oser, B.L.1959. In: Albanese, A.A. (Ed.), An Integrated Essential Amino Acid Index for Predicting the Biological Value of Protein in Protein and Amino Acid Nutrition. Academic Press, New York.

20. SAS Program, 1996. SAS/STAT User's Guide Release 6.12 edition. SAS Inst. Inc, Cary NC, USA.

21. Rose.I.M. and Vasanthakaalam, H. 2011. Comparison of the nutrient composition of four sweet potato varieties cultivated in Rwanda. Am. J. Food. Nutr, 1(1): 3438

22. Salem, Afaf., A. 2010. Selection of new sweet potato lines (Ipomoea batatas L) through true seeds under delta conditions. Minufiya. J. Agric. R., 35(2):1533-1548

23. Shils, M.E.; Olson, J.A.; Shike, M. and Ross, A. 1998. Modern Nutrition in Health and Disease, 9 ed. Williams \& Wilkins, London, UK.

24. Somogyi,M. 1952. Notes on sugar determination. J. Biol. Chem., 195,19-23

25. Walter, W.M.;Truong, V.D. and Sylvia, K.E. 2001. Methods for producing cooked sweet potato products and compositions there of. Washington, D.C: USDA. US Patent 6,197,363 B1. Issued March

26. Yahay,S.U.;Saad, A.M.I; Ohammed, S.C.and Afuape,S.O.2015. Evaluation the per formance of improved sweet potato (Ipomoea batatas $L$ ) advanced lines in kano, sudan savanna of Nigeria. Int. J. Agri. and Agri. Res.,7 (4):52-60 


\title{
إعداد وتقييم الحساء المجفف المنتج من أصناف مختلفة من البطاطا
}

\author{
نصرة احمد عبد الحق 1 - عفاف عبد القادر سالم² \\ 1. معهد بحوث تكنولوجيا الاغذية- مركز البحوث الزراعية الجيزه \\ 2. معهد بحوث البساتين - مركز البحوث الزراعية الجبزه
}

أجريت هذه الدراسة فى محطة بحوث البسا تين بالقناطر الخيرية محافظة القليوبية خلال موسمين

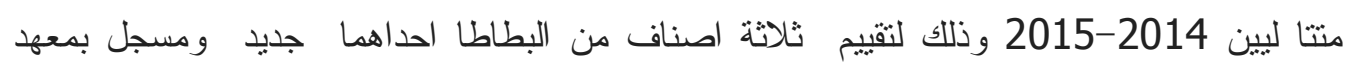

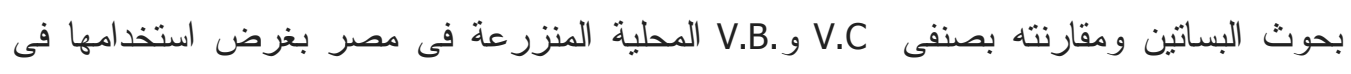

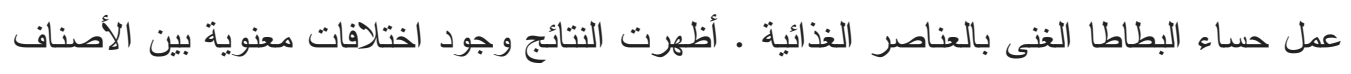
الثلاثة فى معظم الصفات ـ وجود اختلافات معنوية فى صفات نمو المحصول ومكوناته (محصول

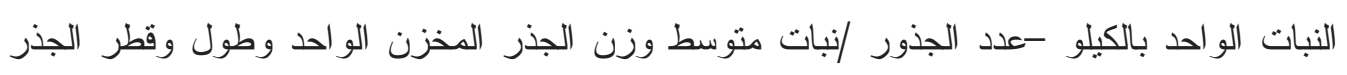

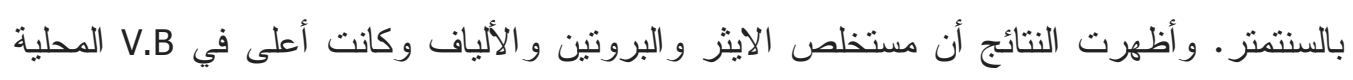
(البطاطا ذات اللحم البرتقالى) من نلك التي وجدت في V.C المحلية (البطاطا ذات اللحم الابيض)

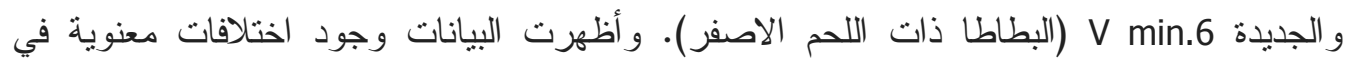

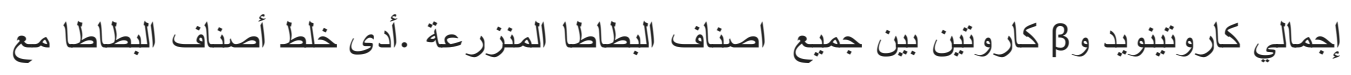
القمح و الحليب منزوع الدسم و العدس إلى تحسين محتوى الأحماض الأمينية و الجودة الغذائية، وهضم

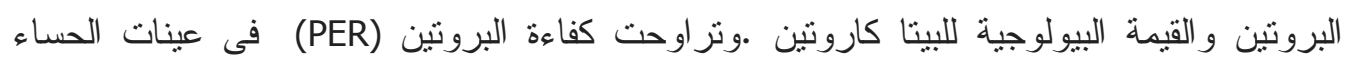
من27, 2 إلى 3,35 ـ و أظهرت النتائج قابلية الحساء الناتج من اصناف مختلفة من البطاطا عن البناء حساء الكنترول (بدون البطاطا). ينصح بتتاول حساء البطاطا لكبار السن والأطفال الصغار لأنه يحتوي على المزيد من البروتين وفيتامين (أ) الذي يعزز البصر . كما سجل الصنف الجديد منوفية 6

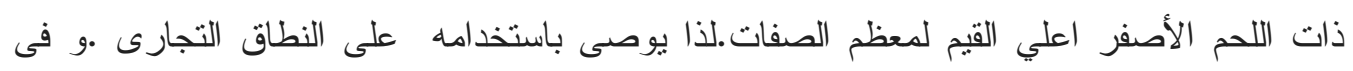
صناعة الحساء.

الكلمات الافتتاحية: البطاطا الحلوة، حساء، والجودة الغذائية والأحماض الأمينية، والخصائص الوظيفية، و التقييم الحسي، بيتا كاروتين. 